\title{
La rima de mèrit a l'Espill de Jaume Roig
}

\author{
Praiseworthy rhymes in Jaume Roig's Espill
}

\author{
Rosanna Cantavella \\ rosanna.cantavellao@uv.es \\ Universitat de València
}

ORCID ID. 0000-002-4424-3659

\begin{abstract}
Resum: Estudi dels tipus de rimes aplicats per Jaume Roig al seu Espill(1460), a través de la quantificació de cada tipus de rima de mèrit (rimes superiors a la bàsica sonança lleial) entre un total de 8104 rimes (s'ofereix una taula de valors absoluts i percentuals a l'annex 1). Els resultats mostren clarament un alt grau d'ocurrència de rims acordants de mèrit (57.8\% del total de rimes), i a dins d'aquests de la lleonismitat en els seus diferents tipus (46.4\%), especialment de terminació femenina. També hi són analitzats els rims diccionals, i a dins d'aquests es remarquen els rims equivocs contrafets tipus 3 com els més emprats d'aquest grup (7.5\%). També s'estudia l'ús per part de Roig de la rima d'homònims (rims equívocs lleials, dels quals s'ofereix una llista a l'annex 2), i es para esment a possibles irregularitats, que Roig usualment evita, i només incorre destacadament en els rims utrisonants, o rima de paraules amb diferent timbre de la $e$ o la $o$, tipus del qual es dóna una altra llista a l'annex 2.
\end{abstract}

Paraules clau: poesia catalana medieval, Jaume Roig, Espill, versificació, rima

Abstract: An appraisal of the rhyme types applied by author Jaume Roig in his Espill (1460), via a quantification of each kind of rhyme of a praiseworthy character (rhymes superior to the basic sonanca lleial) in a total of 8104 rhymes (a table of absolute and percentual values is given in annex 1). Results clearly show a high degree of occurrence of praisenvorthy rims acordants (57.8\% of total rhymes) and within those, of lleonismitat in its different types (46.4\%), especially with feminine endings. Diccional rhymes are also analysed, and within them rims equivocs contrafets tipus 3 are highlighted as the most used of this group (7.5\%). Roig's use of homonym rhymes (rims equivocs lleials, of which a list is given in annex 2) is studied too, and attention is paid to potential irregularities, of which Roig only incurs in rims utrisonants, or rhyme of words with a different openness of vowels $e$ and $o$, of which another list is given in annex 2 .

Keywords: Medieval Catalan poetry, Jaume Roig, Espill, versification, rhymes

\footnotetext{
* Aquest article s'emmcarca en el projecte d'investigació PID2019-105857 GB-I00, del Ministeri de Ciència i Innovació espanyol.
}

DATA PRESENTACIÓ: 11/05/2021 ACCEPTACIÓ: 19/05/2021 ·PUBLICACIÓ: 01/06/2021

SCRIPTA, Revista internacional de literatura i cultura medieval i moderna, núm. 17 / juny 2021 / pp. 36-61 


\section{Sumari}

1. Rims acordants. - 1.1. Consonança lleial. - 1.2 Lleonismitat simple. - 1.3 Lleonismitat perfecta. - 1.4 Lleonismitat plusquamperfecta. - 2. Rims diccionals. - 2.1 Rims derivatius. - 2.2 Rims equívocs lleials. - 2.3 Rims equívocs contrafets. - 2.3.1 Rims equívocs contrafets tipus 1. - 2.3.2 Rims equívocs contrafets tipus 2. - 2.3.3 Rims equívocs contrafets tipus 3. - 2.4 Rims accentuals. - 2.5 Rims utrisonants. - 2.6 Rims trencats. - 2.7 Rims sil labicats. - 3. Els casos intermedis. - 3.1 Rims meritoris. 3.2 Entre consonança i lleonismitats. 3.3 Entre lleonismitat simple i pulsquamperfecta. - 4. Rims cars. - 5. Altres observacions fòniques relacionades amb la rima. 5.1 Consonants mudes en rima. - 5.2 Sonança borda. - 6. Es Roig constant amb la rima de mèrit? - 7. Conclusions. -Bibliografia. .ANNEX 1: Taula de rima de mèrit a l'Espill. ANNEX 2: Rims equívocs lleials a l'Espill. Mostra de rims utrisonants (en sentit ampli) a l'Espill.

El coneixement de què es considerava meritori en català a l'edat mitjana en temes de rima va avançant a ritme lent però segur, obrint-se camí i dissipant els conceptes anacrònics i anatòpics de consonancia i asonancia manllevats del castellà a l'edat moderna.

Recordem que, pel que fa al predomini accentual -bàsic per a valoracions de rima-, l'espanyol es classifica, com el toscà-italià, entre les llengües paroxítones, mentre que el català és, com l'occità i el francès, una llengua oxítona. Si un idioma té predomini de paraules planes, haurà de calcular el mèrit en rima tenint-ho present: serà freqüent que a final de vers queden diversos sons rere la vocal tònica, i s'ha de resoldre què fer amb aquests sons. Així s'explica una certa tolerància de les llengües paroxítones amb l'asonancia, especialment en obres rimades narratives. ${ }^{1}$

Aquesta tolerància no té sentit en llengües de predomini agut, ja que és extremadament fàcil fer concordar tots els sons en terminacions de vers: sovint, entre la vocal tònica i el final de la paraula en rima només hi ha un so, o cap so. Per això la tradició dels idiomes oxítons menysprea l'asonancia, la considera un defecte (entra, com veurem, en el que les Leys d'Amors anomenen sonança borda), i no es consenteix ni tan sols en estructures narratives, com ho són les noves rimades en el cas occità-català.

La consonancia, doncs, entesa com la concordança completa de sons a partir de l'última vocal tònica del vers, es considera el mínim en la tradició poètica medieval d'aquestes llengües; per al que ens afecta, en la tradició trobadoresca. Des d'aquest mínim, però, s'edifica i es classifica un complex sistema de valoració de rimes que ultrapassen en diferents graus i aspectes la dita concordança mínima. Aquest sistema de valoració del mèrit en rima apareix descrit amb molt de detall a les trescentistes Leys d'Amors, a més de -fragmentàriament, i de vegades inacuradament- en altres tractats poètics de la tradició pròpia (Cantavella 2020a i 2020b).

Que el sistema de valoració de rima de mèrit de les Leys d'Amors era conegut i emprat a la poesia de la Corona d'Aragó es mostra no sols en la represa més o menys afortunada que se'n fa en obres posteriors de teoria poètica, sinó també en la pràctica de la tradició versificatòria trobadoresca, des dels clàssics anteriors al s. XIV (mostrant, per tant, que la pràctica va precedir la teoria; que les Leys

1 Per a l'asonancia en català vid. Parramon 1989.

SCRIPTA, Revista internacional de literatura i cultura medieval i moderna, núm. 17 / juny 2021 / pp. 36-61 
sistematitzaven en forma descriptiva i normativa uns usos trobadorescos que venien de molt lluny) ${ }^{2}$ fins a Ausiàs March i els ausiasmarquians posteriors.

Aquests usos de mèrit en rima, doncs, són reconeixibles en totes les obres líriques, i de vegades esmentats en els testimonis de transmissió (vid. nota 15). Però, i les obres narratives en vers? Potser seria esperable en aquestes una certa relaxació de la pruija en l'ús de rima de mèrit, tenint present la subordinació de la forma poètica al missatge argumental?

En aquest treball aplicaré els criteris classificatoris de les Leys a l'Espill de Jaume Roig (1460), i descriuré les tries de mèrit que realitza l'autor als seus 16209 versos tetrasíl labs en 8104 noves rimades. ${ }^{3} \mathrm{El}$ resultat mostrarà un sistema de rimes molt treballat, amb gran densitat i varietat de factors de mèrit.

Per exposar-lo, em caldrà anar definint i exemplificant les unitats d'aquesta arquitectura de factors de mèrit, que genera un sistema plenament escolàstic de nombrosos tipus de rimes valorades per un factor o altre. Cada definició s'acompanyarà amb dades i mostres de l'ús que en fa Roig.

A manera de prefaci, excusació o, com diu la rúbrica, de "consulta", l'Espill va precedit per una peça poètica breu, amb estructura de caire líric (no narratiu, per tant), i amb un esquema ordinal ben curiós (a7 b7 b7 a7 a7 c7 c7 d7); únic, segons Parramon (1993: 131 no. 169.6; 309 no. 152.1), constant de quatre cobles, una endreça i una tornada. No la considere als efectes estadístics que interessen ací, ja que no està construïda en noves rimades sinó, a la manera de la lírica, en cobles creucreuades. Però no m'estaré de dir que els quaranta versos d'aquesta composició prefiguren, en la predominància de rims acordants i diccionals, les tries de l'autor al cos de l'Espill. En quaranta versos trobem vint casos de rimes de mèrit, amb protagonisme de les lleonismitats: tretze, de les quals n'hi ha quatre de femenines, i nou de masculines. Hi trobem també un parell de consonances lleials associades a rims equívocs contrafets tipus 3 (schollir-Llir, he-tambè); i finalment, tres casos de rims meritoris (fuyt-fruyt, treball-tall; valent-atreviment). L'únic que s'hi veu diferent és la tria majoritària de rima masculina sobre la femenina en les lleonismitats (aquesta només en quatre rimes de vint).

Passada aquesta peça proemial, s'inicia ja pròpiament l'Espill, que, en la seua estructura de sermó -que qui signa ja feia notar en 1992, i d'altres han observat també amb posterioritat- presenta com a tema sermonador el famós versicle del Càntic dels Càntics $(2,2)$ tan familiar als seus coetanis per haver inspirat llir entre cards, senyal distintiu d'Ausiàs March. (Recordem que March havia mort en 1459, tot just un any abans de la data oficial de redacció de l'Espill.) El tema va precedit per uns

2 Ja al s. XIX, l'estudiós Karl Bartsch (1859) va cercar la rima de mèrit de les Leys, retroactivament, a la poesia dels trobadors dels segles XII i XIII, i en va trobar nombrosíssims exemples, mostrant que les Leys registraven i catalogaven una pràctica en rima que molt antiga.

3Em guie per l'edició Carré 2014, tant per a la numeració com per a les cites. Com explicaré tot seguit, només tinc presents les noves rimades, així que excloc del còmput els 40 primers versos, que constitueixen la Consulta inicial. Pel que fa a la xifra senar de 16209 versos, s’explica perquè l'últim (“direm: 'Amén”, 16249) és l'únic vers de tot l'Espill lliure de rima. 
versos justificatius del títol triat (com a espill, l'obra ofereix coneixement i directrius als homes, el mateix fi que els specula medievals per a l'ensenyament; i alhora reflecteix, posa en evidència, blasona, les suposades maldats de les dones).

Sabem que l'Espill té una estructura tractadística quadripartida. Els quatre llibres de què consta l'obra, així com el prefaci, van subdividits tots en quatre parts més. Doncs bé, al nivell de la rima, Jaume Roig capcauda aquestes subparts dins de cada llibre. Per exemple, la primera part del prefaci acaba en benignament, i la segona comença amb absent (159-60). ${ }^{4}$ La segona part del mateix prefaci acaba amb notes i la tercera comença amb totes (411-12). ${ }^{5}$ I així sempre entre les parts d'una mateixa unitat llibrària.

En canvi, en el pas d'un llibre al següent Roig defuig el capcaudament, remarcant així els llibres com a unitats completes. El final del llibre primer, per exemple, acaba en honor-major (1953-54), i l'inici del llibre segon, en punt-junt (1955-56).

Roig rarament conculca la regla de les Leys que estableix una mínima distància de vint versos per repetir la mateixa sonoritat en rima. ${ }^{6}$ Però de vegades no hi arriba, com entre espenyada-calsiguada (13151-52) i figurada-entrada (13155-56), amb sols dos versos entremig; igual ocorre entre invençionscondiçions (647-48) i dicçions-relaçions (651-52); entre mia-tenia (1001-02) i homenia-entenia (1005-06), tots ells sols separats per una parella de versos (tot i que en l'últim cas potser Roig aspirava a rims derivatius; vegeu 2.1). En altres casos la separació mínima es transgredeix, però de menys, com entre Déu-veu (11395-96) i féu-véu (11405-06), amb sols 8 versos entre els dos. O entre indignamentçertament (13755-56), amb 10 versos entremig.

Però en la gran majoria d'ocasions els trobem més espaiats, com entre victòria-istòria (12915-16) i dimissòria-executòria (12939-40), entre els quals hi ha 28 versos; o entre càrregua-màrregua (13011-12) i càrregua-sobrecàrregua (13059-60), a 46 versos de distància.

Tampoc no consent mai Roig rimar tres bordons seguits, obeint igualment el consell de les Leys. ${ }^{7}$

Mamprenc tot seguit la presentació de les tries de rima de Jaume Roig. Per fer-ho, i com avançava, és necessari recordar els conceptes rimaris de les Leys d'Amors, prèviament estudiats en detall a

4Donada l'enorme quantitat de remissions que realitzaré a versos de l'Espill, en aquest treball prescindiré de l'abreviatura "vv.", per tal de facilitar una lectura neta.

5 Per al diferent timbre de la o que presenta aquesta parella, vid. infra l'apartat 2.5 dedicat als rims utrisonants.

6"E deu hom notar que [l'acordansa final d'alqun bordo, e mens ades mot tornat,] no deu hom tornar en novas rimadas si .xx. bordo no eran el mieg, quar adonx l'obra seria vicioza per rim tornat” (Fedi 2019: 255-56, L.2 \$17.13). Els claudàtors, tant els rectes com els corbats, són característics de l’edició Fedi.

7 “ $\{$ Pauzar rim tornat en novas rimadas vicis es.\} [quar adonx l'obra desparia, coma si hom comensava alcunas novas rimadas pauzan las acordansas finals dels versetz de dos en dos, ayssi quo es acostumat de far, e pueys ne pauzava tres acordansas finals ad una ma]” (Fedi 2019: 256, L.2 \$17.15).

SCRIPTA, Revista internacional de literatura i cultura medieval i moderna, núm. 17/ juny 2021 / pp. 36-61 
Cantavella 2020a i 2020b, publicacions a què remet per al desenvolupament $\mathrm{i}$ història dels conceptes, i resseguiment en els diferents tractats.

Les Leys divideixen el tipus de valoració del mèrit en rima en quatre apartats, cosa que dóna com a resultat aquests quatre macrotipus de rimes:
A) Estramps
B) Acordants
C) Ordinals
D) Diccionals

De tots, els dos grups més coneguts modernament són el dels rims estramps, i el dels ordinals o combinacions de conjunts de rimes al nivell de la cobla, o de diferents cobles. ${ }^{8}$ Les noves rimades, per l'absència de cobles, exclouen els rims ordinals. D'altra banda Jaume Roig no empra rims estramps, com tampoc rims fènix; així que la meua anàlisi es concentrarà en els rims acordants i en els diccionals, que il lustraré sempre amb exemples extrets de l'Espill, via l'edició Carré 2014.

\section{Rims acordants}

La perspectiva de mèrit del grup dels rims acordants es basa en una valoració quantitativa, i atén al nombre de sons que hi haja en comú entre les paraules en rima. A major quantitat de sons, més mèrit.

Dins els acordants, la rima bàsica mínima acceptable és la sonança lleial, o rima de paraules agudes concordants en sons des de la vocal tònica; per exemple, la rima fredor-llavor (4553-54). Com a rima bàsica, el seu ús no és valorat amb cap mèrit particular.

\subsection{Consonança lleial}

La valoració de mèrit comença amb la consonança lleial, en la qual les paraules agudes tenen en comú també la consonant immediatament prèvia a la vocal tònica, i sovint tota l'última síl laba. Jaume Roig l'empra molt, i n'hi trobem mostres a bastament en cada pàgina. Observeu, per exemple, volguist-creguist (6497-98), odorar-ensofrar (10013-14), o trobarà-volră $\grave{1}^{10}$ (755-56). De vegades, una de les dues paraules no presenta consonant prèvia a la tònica, i això fa més fàcil la consonança, com en arts-brocarts (8037-38).

8 Per als rims ordinals vid. el gran repertori de Parramon (1993). Per als estramps, vid. Pujol 1988-89 i, més recentment, Di Girolamo-Siviero 2002, detallada anàlisi reelaborada a Di Girolamo 2019 (esp. 609-618). Vid. igualment Billy 2005.

9Fedi 2019: 266-67, L.2 \$29; Cantavella 2020a: 269.

10 Considereu que la diferenciació de les ròtiques en bategant i vibrant és molt recent, i que els medievals les havien d'apreciar com el mateix so, simple o múltiple, motiu pel qual les Leys expliquen que cal "doblar" aquest so escrivint la lletra dues vegades (Fedi 2019: 202, L.1 \$51 a 53).

SCRIPTA, Revista internacional de literatura i cultura medieval i moderna, núm. 17/ juny 2021 / pp. 36-61 
He comptabilitzat 922 casos de consonança lleial a l'Espill, d'un total de 8104 rimes apariades, cosa que en representa un important $11.4 \% .^{11}$

Un dels testimonis de les Leys afegeix que hom pot obtenir consonança lleial amb la suma de dues paraules en relació a una altra, operació que denomina consonança contrafeta. ${ }^{12}$ Per exemple, ffort mal mesclà'm, / he posà clam (1045-46); alguns vedells / ab la carn d'ells (1703-04); torna ll reclam? / De coha n l'am (6523-24). Aquest tipus de consonança, ben rar a l'Espill, se solapa ocasionalment amb el tipus diccional de 2.3.2, com veurem.

\subsection{Lleonismitat simple}

El següent graó de mèrit és l'anomenada lleonismitat, o lleonisme, en els seus diferents tipus i graus. En la lleonismitat simple, la concordança fònica s'estén a la vocal plena de la penúltima síl laba, siga aquesta tònica o àtona. ${ }^{13}$ Per tant, poden formar lleonismitat tant paraules agudes com no agudes; és a dir, tant rimes masculines com femenines. ${ }^{14}$ Tot i així, tenint-se present que en llengües oxítones abundaran més les paraules agudes que les no agudes, els poetes prefereixen, quan poden, lluir-se amb lleonismitat de mots no aguts. ${ }^{15}$

He comptabilitzat a l'Espill un total de 2831 lleonismitats simples, que representen un admirable $34.9 \%$ del total de rimes de l'obra sencera. D'aquestes, només 264 (un reduït 3.3\%) estan construïdes sobre terminacions masculines; les 2567 restants (un 31.7\%) ho estan sobre terminacions femenines (més meritòries, com hem dit). Vegem-ne alguns exemples, dels dos tipus.

Lleonismitat simple masculina:

plujós-enujós (1477-78); monet-cerronet (10031-32); dolós-colós (10605-06); volentat-parentat (11049-

50); casament-prestament (11051-52); infirmitat-sanitat (12057-58).

Lleonismitat simple femenina:

Silvestre-mestre (281-82); diablesses-dimoniesses (367-68); arrapaven-pelaven (3383-84); mula-dula (6729-30);

piquen-prevariquen (9821-22); perfeta-neta (10799-800); bojren-partiren (11413-14); sies-vies (12429-30).

11 Per a totes les quantitats tant absolutes com relatives, vegeu la taula de l'annex.

$12 “ . . .\{$ ses meia, quar am meia non es consonansa\} \{veraya mas contrafacha, coma tant es / cortes\}” (Fedi 2019: 267, L.2 \$29.3).

13 Fedi 2019: 267-268, L.2 §30.4-7; Cantavella 2020a: 269-70.

14 No anirà malament recordar, en els temps que corren, que la diferenciació en rimes masculina i femenina no té la menor relació amb la diferenciació sexual, sinó amb la morfologia gramatical: en les llengües romàniques oxítones, les paraules de terminació femenina solen contenir una síl laba més que no les de terminació masculina (estimat-estimada), cosa que fa molt present la diferència mot agut (masculî)-mot no agut (femenî). Vid. Chevrier 1996.

15 Un dels més reeixits del s. XV és el poema, tot en lleonismitats, de Joan Ramon Ferrer (comentat per Cabré 2002, i inventariat per Tomàs 2018: 84), del qual la rúbrica del Cançoner Vega-Aguiló al f. 98r en diu: "Sirventesch, preceptes retoricals observant per leonismitat simpla d'accent greu..." Sobre la importància d'aquest cançoner i la seua connexió amb la tractadística poètica, vid. Alberni 2011.

SCRIPTA, Revista internacional de literatura i cultura medieval i moderna, núm. 17/ juny 2021 / pp. 36-61 
De vegades, la lleonismitat simple es presenta en paraules esdrúixoles, com en exàvegua-tàvegua (5909-10) o càrregua-sobrecàrregua (13059-60), exemple que també veurem a 2.3 .3 i a la secció 4, on també trobarem canònicha-crònicha (8793-94) o rúbricha-llúbricha (8839-40). ${ }^{16}$

Com la consonança contrafeta, també existeixen les lleonismitats contrafetes ${ }^{17}$ com a:

o avançar-me, / pensà matar-me (1021-22); cuytí d'entrar-i: / de un canari (1085-86); ordinari-penssar-i (2383-84); qui apartar-ne / vol que no s'arne (2811-12); per reduyr-la, / jugava birla (3025-26); del neçessari, / pensi d'anar-i (3169-70); molt voluntari, / sens ben guardar-i (6513-14); major vicari, / sens jens mudar-i (3677-78); per alegrar-se / he deportar-se (8341-42); ni dromedari, / ell cavalcar-i (1318788); ho somià. / Bé sé n’i ha (8659-60); o, en contracció per apòstrof, tot en fer lletres, / rebre'n e retre's (5439-40),

tema que tornarem a trobar a les seccions 2.3.1 i 2.3.2.

\subsection{Lleonismitat perfecta}

Quan la concordança fònica inclou la consonant anterior a la penúltima vocal plena, hom ja parla d'una lleonismitat superior, perfecta. Ací també s'inclouen aquelles síl labes que no presenten consonant prèvia a la vocal plena. ${ }^{18}$

Les condicions més restrictives fan que aquesta lleonismitat siga, lògicament, menys freqüent que no la simple. Tot i així, a l'Espill en trobem la considerable xifra de 759 casos, el $9.4 \%$ de totes les rimes de l'obra. D’aquests, 68 (0.8\%) presenten terminació masculina, i 691 (8.5\%), terminació femenina. Ací en tenim algunes mostres.

Lleonismitat perfecta masculina:

partí-apartí (1113-14); dançar-baxadançar (1489-90); tornat-ornat ${ }^{19}$ (3167-68); curaçió-puniçió (1909-

10); component-disponent (4521-22)

Lleonismitat perfecta femenina:

triada-criada (11207-08); descobria-paria (1779-80); torbava-acabava (1791-92); troba-roba (280910); pofembria-seria (4121-22); ploraves-menbraves (6489-90); lloguada-paguada (5107-08); abte-recapte (5093-94).

També en aquesta secció les Leys esmenten una lleonismitat perfecta contrafeta, aconseguida unint paraules; ${ }^{20}$ i certament trobem a l'Espill diversos casos d'aquest tipus, com a:

16 Recordeu que, des del punt de vista mètric, hom només compta fins a l'última síl laba tònica del vers. Aquest precepte fa que calga considerar les terminacions de vers esdrúixoles en el mateix paquet que les planes.

17 “\{Simple leonisme contrafag havem per esta maniera: Yeu no y vey als / Mas qu’es leyals.\}” Fedi 2019: 268, L.2 §30.8-9.

18 Fedi 2019: 268-69, L.2 §30.10-16; Cantavella 2020a: 270-71.

19 Aquests primers tres casos són també rims equívocs contrafets tipus 3; vid. 2.3.3.

20 Fedi 2019: 269, L.2 \$30.17-18.

SCRIPTA, Revista internacional de literatura i cultura medieval i moderna, núm. 17/ juny 2021 / pp. 36-61 
devés Sent Jaume. / Dix-li: "Stojau-me" (3159-60); dix "Despenjau-me! / Beneyt Sent Jaume” (3307-08); gens no n tenia: / sols entenia (5013-14); del fill tan car. / Fferen tancar (4795-96); ragola, teula / calda meteu-la (8163-64).

I, amb contracció apostrofal:

com l'abraçàs, / embaraçàs (58773-74); per sobres d'ira; / de sa cadira (5541-42); conéxer-s'ia / bé tal falsia (6097-98); ni se n'atura / seguint natura (14943-44),

tipus que tornarem a veure en 2.3.1.

\subsection{Lleonismitat plusquamperfecta}

Tot i que les Leys dediquen molt poques ratlles a aquest altre tipus de lleonismitat, ${ }^{21}$ la plusquamperfecta perviu i es manifesta en abundants testimonis. Sembla aplicar-se a casos en què la concordança fònica comença com a mínim a la vocal de l'avantpenúltima síl laba; però l'exemple de les Leys (noyridurapoyridura) va més lluny, ja que comença a la vocal plena de la quarta síl laba comptant des del final.

Hi ha 173 casos de lleonismitat plusquamperfecta a l'Espill, que constitueixen un no menyspreable 2.1\% del total de rimes. D'aquests, 119 (1.5\%) presenten concordança fònica des de l'avantpenúltima vocal plena; 43 (0.5\%) encara des d'abans, com a les rimes femenines arteria-barateria (2965-66); participa-anticipa (8475-76); deçeberen-conçeberen (8633-34); fetilleres-sortilleres (9773-74); alcofollades-afollades (10009-10). I encara més: matrimonis-patrimonis (9887-88); dignificada-deïficada (10925-26) o çerimònies-querimònies (13479-80).

També mereixen esment exemples com maldiçió-perdiçió (10347-48), que presenta terminació masculina amb les tres últimes sîl labes completes. Altres lleonismitats plusquamperfectes masculines són sanament-planament (2059-60), edificat-Magnificat (10761-62), o preservat-reservat (1067374), exemple que a més podem considerar rims equívocs contrafets tipus 3 (vegeu 2.3.3). Només he comptabilitzat 11 casos masculins $(0.1 \%)$ de lleonismitat plusquamperfecta a l'Espill.

\section{Rims diccionals}

El grup dels rims diccionals es configura observant la rima des d'una altra perspectiva: si els rims acordants s'avaluaven quantitativament, segons quants sons establien concordança, els diccionals miren el fenomen de la rima en les seues diccions; és a dir, en els mots que la conformen. Per això, en aquest grup, la valoració reina és la de la rima de paraules homònimes. Hi ha també, però, d'altres aspectes que s'hi valoren, com quants mots conformen la rima, o si una de les paraules en rima sembla derivada de l'altra. Vegem-ho.

\subsection{Rims derivatius}

La particularitat dels rims derivatius és l'emparellament de dos jocs de rima, un dels quals presenta una terminació que fa la impressió (no necessàriament real) de derivar de la de l'altre. Es tracta del

21 Fedi 2019: 269, L.2 \$30.19-20; Cantavella 2020a: 271-72.

SCRIPTA, Revista internacional de literatura i cultura medieval i moderna, núm. 17/ juny 2021 / pp. 36-61 
mateix fenomen que Raimon de Cornet denomina rims entretrets; Jaume March, rims maridats, i el Cançoneret de Ripoll, adjectivats. ${ }^{22}$ Els derivatius ho poden ser per un so/síl laba, o per més. ${ }^{23}$

Els més comuns a l'Espill són els derivats per un so/síl laba, i s’hi troben els següents casos:

\begin{abstract}
Consell-d'ell amb d'ella-parella (2025-28); aquell-cornell amb cornella-parella (3103-06); socarratenganat amb enguanà-demanà (4305-08); sabida-revida amb dides-parides (5211-14); amphibòlichscatolichs amb retòricha-metaforicha (8041-44); pardal-fruytal amb fruyta-cuyta (8439-42); amarinadail luminada amb il luminant-caminant (10981-84; és també per un so o síl laba); elets-perfets amb perfeta-profeta (11727-30); peccà-plorà amb peccat-castiguat (12907-10); i aquest cas doble: calitatvanitat $\mathrm{amb}$ vanitats-iniquitats, $\mathrm{i}$ aquest amb iniquitat-pravitat, $\mathrm{i}$ aquest amb pravitats-peccats (70957102; seqüència, per tant, de vuit versos sobre dues sonoritats maridades). ${ }^{24}$
\end{abstract}

Molt més inusuals són els casos de rims derivatius per diverses síl labes. A l’Espill en trobem tres:

Natural-mal amb malaltia-havia (1345-48); hobeyr-tenir amb tenia-entenia (5011-14); bungüentarispigmentaris amb piments-bungüents (14343-46).

La presència de rims derivatius a l'Espill és insignificant en termes de percentatge ( $0.1 \%)$; però l'aparició d'aquests pocs casos (10 per una síl laba i 3 per diverses; en total 13) necessita ser notada. ${ }^{25}$

\title{
2.2 Rims equivocs lleials
}

Es tracta de la rima de paraules homònimes, inclosa (en termes lèxics moderns) la mateixa paraula amb accepcions que siguen clarament diferents. Els equívocs lleials són els reis de la rima de mèrit, si hem de jutjar per la dificultat que impliquen, i per com de detalladament les Leys aclareixen la diferència entre aquests i els mots tornats o repetició de la mateixa paraula en rima, que els poetes defugen i que hom evita. ${ }^{26}$

Des d'aquest punt de vista, els coetanis devien admirar que a la seua obra, Roig insertara 48 casos d'equívocs lleials, com per exemple:

cosir qu és roma. / La cort de Roma (2769-70); diu que no y creu; / ffent-li la creu (3221-22); lenya molt més, / pi sech y més [de metre] (3617-18); A totes hores / ses belles Hores (3993-94); és en la Seu, / sabeu on seu? (4269-70); han falsa pagua, / si dona ls pagua (8229-30); tantost a coure, / morter de coure (8319-20).

22 Casas Homs 1969: 195, vv. 373-376; Griera 1921: 91, 1l. 2048-71; Badia 1983: rúbriques de 237-39 i 271-23.

23 Fedi 2019: 282-84, L.2 \$50-52. Cantavella 2020b: 4-9. Els dos subgrups es distingeixen perquè els uns només creixen o varien la terminació en un so o en una síl laba, mentre que els altres ho fan en una extensió de més d'una síl laba.

24 Possible també, però més dubtós, veig el següent cas: callau-torbau amb destorbeu-Dén (3989-92)?

25 Aquest no era recurs rar entre els poetes coetanis de Roig; sense anar més lluny, trobem rims derivatius al poema 1 d'Ausiàs March, "Així com cell qui nn lo somni ‘s delita": mort-recort amb aconorta-estorta (Bohigas 2000: 77 vv. 14-18).

26 Fedi 2019: 284-85, L.2 \53.2-6; 211-12, L.1 \$79; 336, L.2 \$106. Cantavella 2020b: 9-17.

SCRIPTA, Revista internacional de literatura i cultura medieval i moderna, núm. 17/ juny 2021 / pp. 36-61 
A l'annex trobareu una llista de rims equívocs lleials amb voluntat d'exhaustivitat, donada la importància medieval d'aquesta mena de rima. Novament, en l'estadística total, representa sols el $0.6 \%$ del total de rimes de l'Espill; però la seua dificultat fa que, en termes absoluts, els 48 casos siguen molt notables.

En parlar dels equívocs lleials, les Leys d'Amors tracten amb detall un fenomen parent, però que en comptes de ser virtut poètica, és vici. Es tracta, com avançàvem, dels mots tornats, o rima d'una paraula amb ella mateixa; fenomen que els poetes defugen. ${ }^{27}$ Roig l'evita sempre, també. L'únic cas en les 8104 rimes de l'Espill que potser podria considerar-se mots tornats és el següent: com l'agre vi / és dit bon vi (6669-70). Però són realment mots tornats? Fixeu-vos que, en el primer vers, l'autor es refereix al vinagre, mentre que en el segon, la significació de la paraula és la general i no específica; i per tant, es podrien considerar accepcions diferents (cas en què es convertirien en equívocs lleials).

\subsection{Rims equivocs contrafets}

Sempre seguint la perspectiva diccional -és a dir, quina mena de paraules creen la rima--, les Leys esmenten tres tipus de rims equívocs contrafets, o imperfectes. No són tan apreciats com els lleials, però són també valorats. N'hi ha de tres tipus:

\subsubsection{Rims equívocs contrafets tipus 1}

Es tracta de rimes en què dues paraules, sumades, rimen amb una altra fent l'efecte de rims equívocs lleials. ${ }^{28} \mathrm{El}$ seu ús és rar a la poesia del s. XV, i a l'Espill només n'he trobat un cas inequívoc: del fill tan car. / Fferen tancar (4795-96). N'hi ha dos més que potser es podrien considerar també: gens no n tenia: / sols entenia (5013-14); ragola, teula / calda meteu-la (8163-64).

Tot i així, i tal com haviem vist a la secció prèvia, hi ha casos de rims acordants contrafets que no queden lluny d'aquestes altres rimes; de fet, el joc de fer rimar una paraula amb dues altres, àdhuc sense equivocitat, ja existia a la poesia llatina medieval. ${ }^{29}$ Per això, a la taula estadística de l'annex, he sumat en el mateix apartat els rims equívocs contrafets $1 \mathrm{amb}$ els acordants contrafets que ja havíem vist, com: yo avançar-me, / pensà matar-me (1021-22); cuytí d'entrar-i: / de un canari (1085-86; lleonismitat simple contrafeta); o "Despenjau-me! / Beneyt Sent Jaume" (3307-08; lleonismitat perfecta contrafeta); i no m'he estat d'incloure aquests tres casos en què la rima aconseguida així no passa de pura sonança lleial (la bàsica): nobles de nau, / ella paguà-u (1827-28); los acolliu?" / He yo sabi-u (1937-38); Tot axís féu. / Bisbe sabé-u (3691-92).

Encara sumant els dits casos, la proporció dels equívocs contrafets tipus 1 (un o tres casos, els primers vistos) més els pocs acordants contrafets a l'Espill és baixa: 20 casos en total (un $0.2 \%$ ).

27 Fedi 2019: 653-56, L.4 §31. Panorama i glossa a Cantavella 2020b: 18-21.

28 Fedi 2019: 285 L.2 \54.1-2. Cantavella 2020b: 22.

29 Vid. Cantavella 2020b: 23-25.

SCRIPTA, Revista internacional de literatura i cultura medieval i moderna, núm. 17 / juny 2021 / pp. 36-61 ISSN: 2340-4841 · doi:10.7203/SCRIPTA.17.20907 


\subsubsection{Rims equívocs contrafets tipus 2}

Aquest tipus de rims contrafets és molt similar a l'anterior, però ací una de les paraules efectua rima amb la contracció resultant d'un parell d'altres, com per exemple qu'oms-coms, o d'aura-daura. ${ }^{30}$ L'Espill no en presenta cap cas de pur.

Però també ací he volgut consignar casos propers als equívocs tipus 2, de rims acordants contrafets, segons havíem vist en la secció prèvia. Per exemple, consonança lleial: ffort mal mesclàm, / he posà clam (1045-46); alguns vedells / ab la carn d'ells (1703-04); torna l reclam? / De coha n l'am (6523-24). O rims meritoris: ffort treballà's ${ }^{31}$ / prest s'emprenyàs (3449-50). O lleonismitats diverses: tot en fer lletres, / rebre'n e retre's (5439-40); com l'abraçàs, / embaraçà's (58773-74); per sobres d'ira; / de sa cadira (5541-42); conéxer-s'ia / bé tal falsia (6097-98); ni se n'atura / seguint natura (14943-44).

A aquests sume els últims cinc casos, que són de simple sonança lleial aconseguida pel mateix mètode: jove pobil, / prest seduíl (5627-28); tots mos anys mals / recogità'ls (6381-82); maten de fam / he dien "da'm" (8177-78); reçuçitàl. / No ss animal (9343-44); servàs-soldàs (10357-58).

\subsubsection{Rims equivocs contrafets tipus 3}

Dels tres tipus d'equívocs contrafets, en la pràctica poètica baixmedieval aquests són els més habituals, amb moltíssima diferència. Es tracta de la rima de dues paraules, una de les quals sembla l'altra amb alguna mena de prefix (no és necessari que ho siga realment). ${ }^{32}$ I molt més que en els tipus contrafets 1 i 2 , els de tipus 3 se simultanegen molt sovint amb mèrits acordants d'un tipus o altre.

Per exemple, amb consonança lleial: alt-desalt (1525-26), any-strany (1647-48), nou-Ninou (1649-50, a continuació de l'anterior); contrafet-fet (9427-28); mil-bumil (11205-06).

O amb lleonismitats diverses:

\begin{abstract}
signe-insigne (8787-88); comuna-una (8801-02); fiau-confiau (4365-66); nora-hora (1361-62); filla-afilla (11161-62); faltes-altes (6547-48); covenia-venia (1969-70); nomenava-menava (4417-18); posadareposada (4449-50); venguda-esdevenguda (7879-80); ampolletes-olletes (8093-94); mamava-amava (9363-64); ovelles-novelles (11409-10); escriví-descriví (11185-86); omplida-complida (11507-08); alçada-exalçada (11847-48); aladre-baladre (12323-24); càrregua-sobrecàrregua (13059-60); demanaemana (14521-22).
\end{abstract}

\footnotetext{
30 Fedi 2019: 285-86 L.2 \$54.3-9. Cantavella 2020b: 22-23.

31 Trie treballà's com a lectura alternativa al treballàs de l'edició Carré, ja que en aquest punt la narració demana indicatiu: 'es va esforçar per emprenyar-se ràpidament'.

32 Fedi 2019: 286 L.2 \$54.12-14. Cantavella 2020b: 23-26.
}

SCRIPTA, Revista internacional de literatura i cultura medieval i moderna, núm. 17/ juny 2021 / pp. 36-61 
O amb lleonismitat plusquamperfecta:

covenia-venia (1969-70); nomenava-menava (4417-18); posada-reposada (4449-50); venguda-esdevenguda (7879-80); ampolletes-olletes (8093-94); mamava-amava (9363-64); ovelles-novelles (11409-10); escrivídescriví (11185-86); omplida-complida (11507-08); alçada-exalcada (11847-48); aladre-baladre (1232324); Psaltiri [libre bíblic]-saltiri [instrument musical] (12599-600, on hauríem pogut considerar com a alternativa uns equívocs lleials); demana-emana (14521-22).

He comptabilitzat 604 casos de rims equívocs contrafets tipus 3, que representen un molt notable $7.5 \%$ de les rimes de l'Espill. A l'hora de considerar-les en el total, tingueu present que, com he dit, aquest $7.5 \%$ se solapa amb percentatges de consonances, lleonismitats i rims meritoris.

\subsection{Rims accentuals}

Les Leys d'Amors de vegades són prescriptives i de vegades són, simplement, descriptives. Esmenten els rims estramps de mèrit, però també els rims estramps sense mèrit, a evitar; descriuen la sonança lleial, però també la sonança borda. Per tant, no ens hem d'estranyar que s'ocupen de rims particulars com els accentuals, els utrisonants, els trencats i els sil labicats, tot i valorar-los negativament.

Les Leys consideren rims accentuals aquells en què dos mots presenten la mateixa terminació, però diferents posicions de la vocal tònica (per exemple, costa-costä). ${ }^{33}$ Aquest tipus combinatori no interessa als dels poetes de la tradició trobadoresca, i tampoc sembla agradar a Roig, que no n'empra cap cas pur -és a dir, paraules que, de no ser per la diferència d'accent, serien homònimes.

Tot i així, i igual que he fet amb els rims equívocs contrafets, he aprofitat per a considerar en l'apartat dels accentuals aquells casos de terminacions amb tonicitats diferents tot i no donar-se potencial equivocitat perfecta. Des d'aquesta perspectiva més àmplia, tampoc no he trobat més que una sola mostra clara de rims accentuals a l'Espill: Hieú [Jeü] ${ }^{34}$-féu (15791-92), parella ja remarcada per Carré com a rima visual (2006: 63-64). La resta son casos que sols tangencialment podrien considerar-se com a tals.

Prenguem el cas alfereçia-epilençia (5245-46). Epilencia (o, potser, epilència, per 'epilèpsia') té dues ocurrències, segons el CICA, a la versió catalana del Cànon d'Avicenna, fols 50r i 103r; aquesta és una obra en prosa, així que no ens proporciona pistes respecte de la seua habitual pronunciació. Podem estar segurs que es tracte de rims accentuals, i descartar completament que la pronunciació medieval d'aquest terme mèdic fos plana?

També és dubtós si hi haja rims accentuals en la parella falsia-geumençia, 'geomància' (4611-12), ja que aquesta darrera paraula torna a aparèixer $i$, quan ho fa, de nou presenta la i tònica, igual que la

33 Fedi 2019: 288 L.2 \55; 336, L.2 §107; 286 \54.10-11. Cantavella 2020b: 26-28.

34 Que la pronunciació esperable fos Je-ú i no I-eu se sospita, però no es pot comprovar, a l’altre vers en què apareix esmentat aquest personatge: per Hieú rey (13153).

SCRIPTA, Revista internacional de literatura i cultura medieval i moderna, núm. 17/ juny 2021 / pp. 36-61 
seua parella: ab geumençia, / nigromançia (9779-80). I no és perquè Roig no tingués present on duien la tònica les paraules en -ància (223-34, 11467-68, 12255-56).

Hi ha, a més, el cas psalmodia-venia (13253-54). Imagine que es tracta d'un desplaçament voluntari de l'accent; però difícilment podem estar-ne segurs, ja que l'únic testimoni antic registrat tant pel CICA com pel DTCA de salmòdia són els Diàlegs de Sant Gregori, una altra obra en prosa que tampoc no ens en dóna pistes.

Finalment, convé esmentar els versos Anastasia, / Agnès, Lluçia (15261-62), on hem de considerar Llucia plana per quantificar el vers com a tetrasil làbic. Igualment amb el vers anterior; però què fer amb l'Anastasia? Per a nosaltres, el mot és inequívocament esdrúixol, i considerem tònica principal la penúltima a. Però i per als catalanoparlants del segle XV? Aquest no és un antropònim freqüent ni tradicional a la Corona d'Aragó, ${ }^{35}$ s'associa més bé amb els móns grec i eslau. Creu Roig, creuen els seus coetanis, que la correcta pronúncia d'Anastasia és plana, com la de malvasia?

Una tal escassetat de casos de rims accentuals (representant els dubtes acabats d'indicar, n'he comptabilitzat artificialment dos) apunta, justament, a com Roig evita recórrer a aquest subterfugi.

\subsection{Rims utrisonants}

També en aquest cas, les Leys evidencien un afany purament descriptiu, ja que, com en el cas anterior, condemnen l'ús d'aquest tipus de rima. Les Leys apliquen aquesta nomenclatura, en sentit estricte, a casos de paraules que constituirien rims equívocs si no fóra perquè les vocals tòniques $e$ $\mathrm{o} o$ presenten timbres diferents (rima de vocal tancada amb vocal oberta). ${ }^{36}$

A l'Espill només n'he trobat un cas en sentit estricte: dóna-dona (9993-94). Ara bé; en un sentit ampli (prenent tota rima de vocals de timbres diferents, i no sols les que serien homònimes), de totes les rimes condemnades per les Leys, les utrisonants són les més emprades per Roig. D'aquestes, n'he comptabilitzat 80 casos (un 1\% del total de rimes), com per exemple boAraguó (7217-18); coll-foll (7921-22); sols-pols (8301-02); féu-preu (11627-28); menyspreu-deu [verb] (13723-24); vе́u-juheu (14017-18).

Algunes d'aquestes rimes, a no ser per la diferència vocàlica, haurien format consonança lleial (5 casos, un 0.1\%), com a honor-or (3751-52); fos-os (10309-10), i açò-lliçó (14979-80); o bé haurien format lleonismitat d'un tipus o altre (24 casos, un 0.3\%), com a poble-noble (3723-24), bona-stona (4577-78), respectes-sectes (4951-52), banyadora-hora (2695-96), axò-caxó (3065-66), resona-persona (832122) i altres formes de mèrit, com a tisores-dos hores (889-90) o preycador-Boca d'Or (11813-14), que haurien estat lleonismitats contrafetes.

35 No en trobem una sola ocurrència, per exemple, als índexs de Rubio-Rodrigo 1997.

36 Fedi 2019: 287 L.2 \54.15-16; 288-89 L.2 \56; 336-337, L.2 §107. Cantavella 2020b: 28-29.

SCRIPTA, Revista internacional de literatura i cultura medieval i moderna, núm. 17/ juny 2021 / pp. 36-61 ISSN: 2340-4841 · doi:10.7203/SCRIPTA.17.20907 
Sovint les desviacions de la norma aporten més informació sobre casos lingüístics que no el seguiment de la norma. Per això trobareu a l'annex una llista de casos d'utrisonants en sentit ampli a l'Espill.

Per què Roig, que mostra una pruija considerable a l'hora de triar rima de mèrit i defugir defectes, abunda en rims utrisonants? Cal recordar que els timbres de $e$ i $o$ es diferencien més, generalment parlant, en el català occidental que no en l'oriental. ${ }^{37}$ Això porta a sospitar que, o bé Roig no considerava important incórrer en aquest tipus de rima, o bé ell no diferenciava gaire aquests timbres.

A títol particular, tanmateix, jo m'incline per la primera opció; si més no per una qüestió estadística: aquest $1 \%$ no pot considerar-se representatiu d'una indiferenciació vocàlica; n'hauríem trobat moltíssims més casos, entre el 99\% de rimes restants.

\title{
2.6 Rims trencats
}

Els trencats i els sil labicats són les varietats més estrambòtiques de rimes. En els trencats, es tracta de literalment segmentar una paraula de manera que una part quede en posició de rima, i la resta es complete al vers següent. ${ }^{38}$ Les Leys només n'ofereixen com a exemple aquests versos:

Filha de Dieu, verges e may-

Re, [gardatz me del Satham lay]-

Ro [desleyal] si que dece-

Bre m'arma no puesca de re. ${ }^{39}$

Les Flors del gai saber, en canvi, ofereixen aquests altres:

\author{
Mayres de Dieu, humils e gra- \\ Ciosa, flors e mot beuta- \\ Doza pregatz vostre fill pre- \\ Cios ques el m'aja merce.
}

\begin{abstract}
37 En la cita que segueix, en què el famós Resum de poètica catalana ataca el tema del que són per a les Leys rims utrisonants, l'observació que he marcat en cursiva resulta estranya als catalans occidentals: "En català, la mena més perillosa de falses rimes, per la dificultat de saber el so obert o tancat d'una e o d'una o accentuades fins que no s'hagi publicat el diccionari de rimes que està preparant Pompeu Fabra, és la que pretén fer rimar, com a versos consonants, paraules acabades en vocal oberta amb altres acabades en tancada: cor i amor, després i desprès, peix i mereix. És ben clar que essent aquesta mena de falses rimes menys grossera que les anteriorment denunciades, sigui més perillosa, perquè és més corrent $\mathrm{i}$, aparentment, disculpable. Però tothom que tingui una oïda cultivada, no pot sentir-les sense experimentar la impressió desagradable que en resulta" (Serra-Llatas 1932: 71). A banda la curiosa informació que Fabra preparava un diccionari de rimes (avui per desgràcia perdut), remarquem que la redacció està clarament dirigida a parlants orientals. Sobre obertures de vocals en els registres geogràfics vid. Carrera i Fernández 2005. Sobre poetes moderns indiferenciant obertes i tancades vid. també Badia i Margarit 1988.
\end{abstract}

38 Fedi 2019: 732 L. 4 \$113.3-8, on es relacionen amb la temesi.

39 Fedi 2019: 211 L.1 \$77.

SCRIPTA, Revista internacional de literatura i cultura medieval i moderna, núm. 17/ juny 2021 / pp. 36-61 
Amichs totz jorns me fayts cossi -

Rar fort lo pretz ella noble-

Sa de midons quez es corte-

Sa e vers lums e fons veraya. ${ }^{40}$

No pot estranyar que els poetes de la tradició trobadoresca, als segles XIV i XV, no facen ús d'aquesta opció de rimes; i que les pròpies Leys tampoc no n'aconsellen l'ús.

L'únic cas inequívoc de rims trencats a l'Espill és el passatge com bou remuga, / com féu Nabugua/ donosor, rey (12189-91), on hom veu que l'autor no tenia altra opció per encaixar aquest mot hexasil làbic més que trencar-lo.

De casos dubtosos, en tenim alguns altres. Es tracta de passatges que impliquen pronoms personals àtons. Vegem-ne: "com qui torcar- / se vol la boca" (3546-47); "sols encartar-/ li l'exovar" (394748); "car infestant-/ me la priora” (5976-77). Podem parlar de trencament, ací? Fa difícil de dir. Des del punt de vista nostre, contemporani i fabrià, per descomptat que sí. Però els pronoms febles medievals, almenys els de l'Espill, són ben variables en posició i en forma (Cantavella-Miralles 1984), i la seua manifesta fluïdesa fa pensar que els medievals potser no veien com un trencament pròpiament dit la separació dels casos citats. Ara bé: precisament el fet que hi haja ben pocs casos pesa a l'altre costat de la balança, ja que sembla indicar que l'autor defuig el desmembrament quan pot.

\subsection{Rims sil labicats}

Aquests són una variació dels anteriors. Als trencats sols es trencava la paraula en rima; ací, se'n permuten les síl labes, que són recol locades entre altres paraules, en rima o no. Les Leys en diuen ben poc: reconeixen aquesta mena de jocs com extremadament inusuals, i n'ofereixen un sol exemple. ${ }^{41}$ L'exemple és représ per Joan de Castellnou al seu compendi, que ens fa el favor de desembolicar les síl labes a continuació de cada vers:

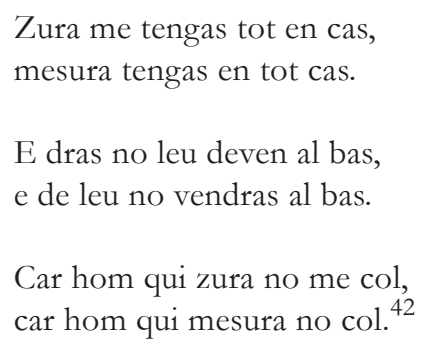

I així successivament. Jaume Roig no els empra gens.

\footnotetext{
40 Anglade 1926: 62, vv. 2436-39; i 48, vv. 1055-59, respectivament.

41 Fedi 2019: 337 L.2 \$110; i 733, L.4 \$113.13.

42 Maninchedda 2003: 129-130, §48.
}

SCRIPTA, Revista internacional de literatura i cultura medieval i moderna, núm. 17/ juny 2021 / pp. 36-61 


\section{Els casos intermedis}

Tots aquests tipus de rima explicats no es donen en compartiments isolats, sinó com un ventall de manifestacions. Això fa que, sovint, es presenten casos a cavall entre un tipus de rima i un altre. Ací us n'oferesc unes mostres:

\subsection{Rims meritoris}

Existeix un tipus de rima que la teoria de les Leys no considera, però que la pràctica poètica baixmedieval manifesta sovint. El tipus, que solc denominar senzillament rims meritoris, és aquell en què dues paraules agudes, a més de compartir els sons des de la vocal tònica (és a dir, a més de complir la sonança lleial bàsica), en comparteixen d'altres de consonàntics, però no en la mateixa posició prèvia a la tònica (per la qual cosa la seua rima no pot ser classificada com a consonança, ni com a lleonismitat).

Dit altrament: en rima masculina de paraules agudes, es tracta de la repetició d'almenys una consonant prèvia a la vocal tònica en posicions diferents. No compte la sola repetició de vocals, perquè d'aquestes només n'hi pot haver cinc (timbres de vocals àtones en sistema occidental) i per tant, la concordança pot ser no deliberada.

Alguns rims meritoris són molt notables: Tamar-matar (9371-72); strany-estany (9425-26); paraýs-parís (10405-06); cuytant-cuydant (4851-52); tanbor-tamor (12757-58); descominals-animals (13435-36).

Ara bé, la necessitat de concretar com a definició de mínims la repetició de consonants no en rima, du a acceptar també com a rims meritoris d'altres parelles més modestes, com aquestes:

\footnotetext{
Entrametent-puntacorrent [ròtica i nasal+oclusiva dental] (1995-96); convenient-inpertinent [nasal més o menys alveolar] ${ }^{43}$ (11743-44); passats-ajustats [sibilant sorda] (8205-06); preycar-sopar [bilabial sorda] (13269-70); fallir-fogir [labiodental sorda] (13283-84).
}

Aquest tipus de rima, doncs, és meritòriament modesta. A l'Espill n'he comptabilitzat 742 casos, amb un percentatge de $9.2 \%$ sobre el total de rimes. Modestes, però superiors a la rima bàsica, la sonança lleial.

\subsection{Entre consonança i lleonismitats}

Tot $\mathrm{i}$ la freqüent especificitat de les Leys pel que fa a les diferents rimes, aquestes no poden ser exhaustives, i freqüentment trobarem casos que van més enllà d’un tipus, però no arriben al tipus següent.

Ho veiem en no rares consonances lleials que s'estenen parcialment a la síl laba anterior. Vetne alguns exemples: beureu-aureu (951-52); llibertat-eretat (1121-22); pogui-dispongui (4917-18); ençertit-

43 No podem aplicar retrospectivament la finesa que la fonètica moderna empra en dentificar el punt d'articulació. Per als medievals, les idees de so i la de lletra van molt més unides que no per a nosaltres. La $n$ té per a ells un únic so, ja que ells jutgen pel resultat sonor, més que no pel procés d'articulació.

SCRIPTA, Revista internacional de literatura i cultura medieval i moderna, núm. 17/ juny 2021 / pp. 36-61 
partit (4947-48); furtat-apartat (6859-60); vixcut-crexcut (9409-10); apartat-transportat (10293-94); amistat-malvestat (10447-48); naxqué-vixqué (10515-16); temps-stremps (10939-40); mester-fuster (11085-86); eternalment-felment (12573-74); ffrederical-fiscal (12991-92); cuynés-faynés (2503-04); presentà-contà (6379-80).

De vegades, aquest tipus de casos intermedis ens fan pensar (sense ser-ho) en la lleonismitat perfecta, com per exemple a: pensaments-sarments (3615-16); parir-perir (4645-46); jurats-girats (747172); mengà-menegà (10417-18); lleguà-lliguà (10477-78).

A l'hora del còmput els he classificat tots a la baixa, com a consonança lleial.

\subsection{Entre lleonismitat simple i pulsquamperfecta}

De la mateixa manera hi ha lleonismitats que en sentit estricte són simples, però que sonen a perfectes, com a:

\footnotetext{
Mossényer-estrényer (4217-18); carabaça-abraça (4275-76); acostassen-entrassen (4447-48); desesperadadespenjada (4895-96); boca-broca (2481-82); faràs-fartaràs (9989-90); cara-clara (10027-28); fonerenferen (10043-44); delliberada-forçada (10461-62); gercaren-adoraren (11437-38); vestien-estenien (13227-28); pressa-peça 4263-64.
}

I fins en alguns casos sonen a plusquamperfectes:

colona-corona (13867-68); babarota-babota (5557-58); matexa-madexa (13907-08); filava-fiava (139798); furiosa-perillosa (3799-3800); coronats-ordonats (3741-42); fellones-lleones (6777-78); ginebregingebre (2527-28); salmedines-madrines (3467-68); riera-ribera (7641-42); malaltia-mataria (8103-04); desmamen-desamen (9839-40).

Igualment, i malgrat tot, he classificat aquests casos sempre a la baixa, com a lleonismitats simples.

\section{Rims cars}

Tot i que les Leys d'Amors esmenten els rims cars, semblen donar-los per sabuts i no els defineixen; i certament, és fàcil deduir-ne el significat pels pocs passatges que els esmenten, on és de notar que s'empren en escala (més cares o menys cares). ${ }^{44}$

És, en canvi, un dels tractadets poètics ripollesos, Ripoll 2, qui en presenta millor definició:

Rimes cares son aqueles de que hom troba poques, axi con aqueles que termenen en -obra (o enquar -uer, o en -aygua, e -iun, -u) o en -ampa o en -endi o en -atxa o en imbre, o semblans rimes de que hom troba poques (Marshall 1972: 105, rr. 137-40).

44 ...per autras rimas $\{. i$ pauc $\}$ caras... (Fedi 2019: 802, L5 \$2.49); ...per autras rimas longas mays caras... (803, L5 $\$ 2.61) ; . .$. e miels pauzadas et en pus caras rimas... (803, L5 $\$ 2.63) ;$...tals rims que sian tan cars que no 'n puesca trobar mays .X. solamen... (806, L5 \$3.5). 
Únicament l'escassetat, la raresa, doncs, és el que marca la valoració (i la denominació) dels rims cars, i així ho sintetitzà Martí de Riquer referint-se al passatge susdit (1975: 1, 40):

El tratadista, que toma algunos de estos ejemplos de Arnaut Daniel (concretamente de la canción Doulz brais e critz, 117), advierte la rareza de estas consonancias, que es lo que las hace "caras", pero no repara en su sonoridad o posibles valores fónicos, onomatopéyicos o aliterativos buscados por algunos trovadores.

Hi hauria rims cars, doncs, quan les terminacions en rima són escasses en la llengua emprada pel trobador. Tant en occità com en català, les paraules no agudes no són tan habituals com les agudes, així que els rims cars solen donar-se entre paraules planes o esdrúixoles, com veurem. Com que és molt difícil, per la pròpia relativitat dels rims cars, establir un límit clar entre terminacions escasses i terminacions que no ho són tant, no he considerat convenient comptabilitzar aquests tipus de rima. Tanmateix, us oferesc una àmplia mostra del seu ús a l'Espill.

Rims cars en paraules planes:

\begin{abstract}
oscha-moscha (2493-94); cofre-girofre (2517-18); fulla-agulla (2767-68); pardos-alardos (2701-02); surta-murta (2883-84); repudi-estudi (3095-96); forro-corro (3177-78); recapte-disapte (3711-12); titolscapitols (3715-16); oferta-concerta (3781-82); exorba-torba (4255); inábil-llabil (4491-92); burça-sturça (5069-70); pràtich-fleumàtich (5821-22); taronga-monga (5827-28); barbes-alarbes (7467-68); atzebresvebres (7771-72); ètichs-crètichs [potser per critics] (8201-02); corruptes-duptes (9607-08); Alexandreçeliandre (9721-22); foçil-dòçil (10329-30); tehològichs-llògichs (10749-50); delicte-edicte (11297-98); Antòfol-Cristòfol (11817-18); colzes-polzes (16111-12).
\end{abstract}

Rims cars en paraules esdrúixoles:

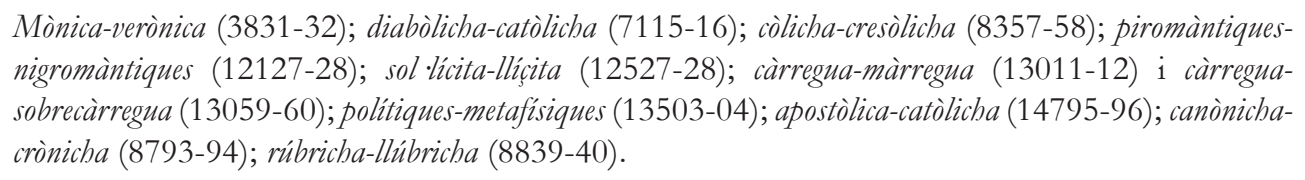

Aquesta significativa presència de rims cars a l'Espill mereix, doncs, ser notada i remarcada. Tot i així, no hem de perdre de vista que els rims cars són molt més fàcils d'aconseguir en un simple apariat que no ho serien en un poema d'estructura lírica (per exemple, un en cobles unisonants). 


\section{Altres observacions fòniques relacionades amb la rima}

\subsection{Consonants mudes en rima}

Com haureu observat en alguns exemples, en alguns casos Jaume Roig no considera per a la rima les consonants mudes. I així, emparella sense comptar la t, casos com mans-galants (301-02), gransinfants (2313-14), ciutadans-gualans [galants] (2627-28), béns-parens (1153-54), capitans-tants (13649-50) o gens-gents (15181-82, 16173-74). Igualment prescindeix de la $p$ muda en temps-rems (4229-30). Ara bé, aquests casos són rars.

\subsection{Sonança borda}

Quant a la rima de paraules en què no hi ha perfecta concordança de les consonants rere la vocal tònica, ${ }^{45}$ sols he trobat en tot l'Espill vuit casos de sonança borda. En rima masculina, casats-asts (2243-44); gests-fets (4377-78); freschs-grechs (5235-46); companyons-jorns (7831-32) i tests-fets (7957-58). I en rima femenina, incrèduls-hèmuls (3807-08) i els numerals onz̧e-quatorže (8951-52) i dotz̧e-quatorze (11031-32).

\section{6. És Roig constant amb la rima de mèrit?}

En general, la freqüència d'ús per part de Roig de formes meritòries en rima sol ser bastant constant; i si, com veureu a la taula de l'annex, hi ha més ocurrències de tota mena als llibres segon i tercer, en general això s'explica perquè són les parts més extenses, amb molta diferència. Això no deixa que de vegades apareguen passatges notables, com el fragment 3963-4706 (llibre 2, final de la part 2 (Beguines) i inici de la part 3 (Viudes), on les lleonismitats són quasi constants. Però de nou, si mirem els versos anteriors i els posteriors, apreciarem que també hi ha gran presència de lleonismitats, cosa que fa difícil concloure res de particular, excepte el gust de Roig per aquest factor meritori.

Tot i així, em va cridar molt l'atenció un passatge al llibre 3 part 2 on, dins una secció amb relativament pocs equívocs contrafets tipus 3, de colp n'apareixen molts de seguits (10551-708):

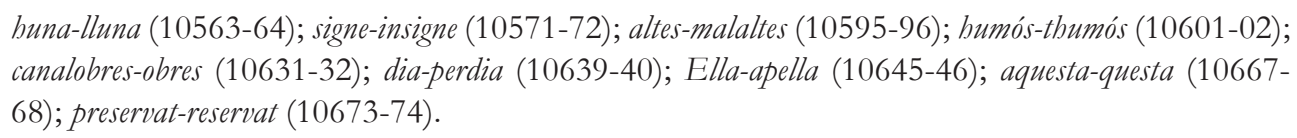

A aquesta superabundància de tipus 3 , s'hi sumen també totes les altres formes de rima de mèrit, $\mathrm{i}$ s'hi crea una gran densitat. El passatge presenta la particularitat de centrar-se en la lloança de la Mare de Déu, inclosa l'espinosa qüestió de la immaculada concepció. Va escriure Roig aquest passatge en un moment particular, potser abans, potser a part de la resta? O estava Roig especialment inspirat?

45 Fedi 2019: 263, L.2 \$24-25.

SCRIPTA, Revista internacional de literatura i cultura medieval i moderna, núm. 17/ juny 2021 / pp. 36-61 
En tot cas, aquest no és l'únic passatge dens; per exemple, la densitat de rima de mèrit a la tercera part del prefaci és molt notable, amb la lleonismitat com a reina entre els casos que s'hi inclouen.

Molt dens també és el llibre 2 en la quarta part (Monges); però crida l'atenció la inusual escassetat de rima de mèrit a la història de la monja "Merlina" que intenta seduir un jove i aquell es nega per no fer Déu cornut (5624-5724), i a la següent, de la monja i el confessor (5725-5759). Després ja es reprén en bona part la densitat habitual.

\section{Conclusions}

Hem vist com Jaume Roig fa ús sovintejat de rima de mèrit de tota mena, fins al punt que hi ha moltes més rimes de mèrit a l'Espill que no rimes bàsiques: d'un total de 8104 rimes, només els rims acordants (consonances lleials, lleonismitats de tota mena) ja en representen el $57.8 \%$, i particularment les lleonismitats en conformen un 46.4\%. Pel que fa als rims diccionals, és molt destacable l'ús dels rims equívocs contrafets de tipus 3 (sovint solapats amb lleonismitats), amb un considerable $7.5 \%$ sobre el total de rimes.

També hem vist que aquest autor defuig les llicències en rima amb una excepció: ocasionalment, empra rima en forma utrisonant.

En conjunt, Jaume Roig aplica rigorosament i amb gran perícia el sistema de rima de mèrit de la tradició trobadoresca, cosa que no pot sorprendre, perquè no hi havia sistema de valoració alternatiu a aquest. De fet, una ullada a les obres poètiques del certamen replegat a l'incunable de les Trobes en laors de la Verge Maria en què Roig va participar, ens mostra que cap a 1474, els usos dels rims meritoris seguien plenament en vigor entre els poetes en català, inclòs el propi Roig. Un segle més tard, l'autor de la Nova art de trobar atribuïda a Francesc d’Olesa (vid. Rossich 1991, Vidal Alcover ed. 1986) ja necessitava insistir en la importància de conservar una tradició poètica que veia que s'anava perdent. 


\section{Bibliografia}

Alberni, A. (2011) "L'última cançó dels trobadors a Catalunya: el Cançoner Vega-Aguiló i la tradició manuscrita llenguadociana", dins Leonardi, L. (ed.) La tradizione della lirica nel Medioevo romanæo: problemi di filologia formale, Firenze, Edizioni del Galluzzo, pp. 109-152.

Anglade, Joseph, ed. (1926) Las Flors del Gay Saber, Barcelona, Institut d'Estudis Catalans/Fundació Patxot.

Badia, Lola (1983) Poesia catalana dels. XIV : edició i estudi del "Canconeret de Ripoll”, Barcelona, Quaderns Crema.

Badia i Margarit, A.M. (1988) "Les oposicions fonològiques e/ع i o/o a les rimes dels poetes moderns", al seu Sons i fonemes de la llengua catalana, Barcelona, Universitat de Barcelona, pp. 105-140.

Bartsch, K. (1859) “Die Reimkunst der Troubadours", Jahrbuch für Romanische und Englische Literatur, 1, pp. 171-197.

Billy, D. 2005, "Remarques inédites sur les stramps catalans", dins Billy, D. I Buckley, A. (eds.) Etudes de langue et de littérature médiévales offertes à Peter T. Ricketts à l'occasion de son 70ème anniversaire, Turnhout, Brepols, pp. 531-543.

Bohigas, P., ed. (2000) Ausiàs March Poesies, Barcelona, Editorial Barcino.

Cabré, M. (2002) "El saber de Joan Ramon Ferrer", dins Badia, L, Cabré, M. i Martí, S. (eds.) Literatura i cultura a la Corona d'Aragó (segles XIII-XV). Actes del III Col toqui Problemes i mètodes de literatura catalana antiga (Girona 2000), Barcelona, Curial/Publicacions de l'Abadia de Montserrat, pp. 228-258.

Cantavella, R. i Miralles, V. (1984) "Aproximació als pronoms adverbials i personals febles de l'Espill”, Quaderns de Treball, 1, pp. 11-20, DOI http://dx.doi.org/10.17613/02fs-ga09.

Cantavella, Rosanna (1992) Els cards i el llir: una lectura de l'Espill de Jaume Roig, Barcelona, Quaderns Crema.

- (2020a) "Versus leonini, lleonisme, léonime: la rima de dues síl labes en la teoria poètica trobadoresca, amb els seus contraparts llatí i francès”, Revista de Literatura Medieval, 32, pp. 73-97, DOI https://doi.org/10.37536/RLM.2020.32.0.77079.

- (2020b) "La teoria dels rims diccionals als manuals poètics trobadorescos i el seu context", Lecturae tropatorum, 13, pp. 1-43, http://www.lt.unina.it/Cantavella-2020S.pdf.

Carré, Antònia, ed. (2006) Jaume Roig Espill, Barcelona, Quaderns Crema.

—. (2014) Jaume Roig Espill, Barcelona, Barcino.

Carrera-Sabaté, J., i Fernández Planas, A.M. (2005) Vocals mitjanes tòniques del català: estudi contrastiu interdialectal, Barcelona, Horsori.

Casas Homs, Josep Maria, ed. (1969) Joan de Castelnou Obres en prosa: Compendi de la coneixença dels vicis en els dictats del Gai Saber; Glossari al "Doctrinal" de Ramon de Cornet, Barcelona, Fundació Vives Casajuana.

SCRIPTA, Revista internacional de literatura i cultura medieval i moderna, núm. 17/ juny 2021 / pp. 36-61 
Chevrier, Alain (1996) Le Sexe des rimes, Paris, Les Belles Lettres.

CICA: Corpus Informatitzat del Català Antic, http://www.cica.cat/.

Di Girolamo, C. 2019, "La versification catalane médiévale entre innovation et conservation de ses modèles occitans", al seu Filologia interpretativa, Roma, Edizioni di Storia e Letteratura, pp. 599-627.

Di Girolamo, C., i Siviero, D. (2002) “D’Orange a Beniarjó (passant per Florència). Una interpretació dels estramps catalans", Mot So Razo, 1, pp. 32-39.

DTCA: Diccionari de Textos del Català Antic, http://www.ub.edu/diccionari-dtca/.

Fedi, B. (2019) Las Leys d'Amors: redazione lunga in prosa, Firenze, Edizioni del Galluzzo.

Griera, A. (1921) Diccionari de rims de Jaume March, Barcelona, Institut d'Estudis Catalans.

Maninchedda, Paolo, ed. (2003) Joan de Castellnou Compendis de la conexença dels vicis que s podon esdevenir en los dictats del Gay Saber, Cagliari, Cooperativa Universitaria Editrice Cagliaritan.

Marshall, J. H. (1972) The "Razos de trobar" of Raimon Vidal, and Associated Texts, London, Oxford University Press.

Parramon i Blasco, J. (1993) Repertori mètric de la poesia catalana medieval, Barcelona, Curial Edicions Catalanes/Publicacions de l'Abadia de Montserrat.

—. 1989, "Consideracions sobre l'assonància", dins Estudis de Llengua i Literatura Catalanes, vol. 18, Barcelona, Publicacions de l’Abadia de Montserrat, pp. 129-138.

Pujol, J. 1988-89, "Els versos estramps a la lírica catalana medieval”, Llengua \& Literatura, 3, pp. 41-87.

Riquer, M. de (1975) Los trovadores, Barcelona, Planeta.

Rossich, Albert (1991) 'Francesc d'Olesa i la Nova Art de trobar", dins Miscel.lània Joan Fuster. Estudis de Llengua i Literatura, vol. 3, Barcelona, Publicacions de l'Abadia de Montserrat, pp. 267-298.

Rubio Vela, A., i Rodrigo Lizondo, M. (1997), Antroponímia valenciana del segle XV, València/ Barcelona, IIFV/PAM.

Serra i Baldó, A., i Llatas, R. (1932) Resum de poètica catalana: mètrica i versificació, Barcelona, Barcino.

Tomàs, A. 2018, "El sirventès en la poesia catalana dels segles XIV-XV: un catàleg", Magnificat Cultura i Literatura Medievals, 5, pp. 71-114.

Trobes en laors de la Verge Maria (1474), València, Lambert Palmart.

Vidal Alcover, J. ed. (1986) Francesc d'Olesa Art nova de trobar, Palma/Barcelona, Universitat de les Illes Balears/Publicacions de l'Abadia de Montserrat. 
ANNEX 1: Taula de rima de mèrit a l'Espill

\begin{tabular}{|c|c|c|c|c|c|c|c|}
\hline & Total rimes & \begin{tabular}{|l|} 
Total rimes \\
$\%$
\end{tabular} & & \begin{tabular}{|l|} 
Llibre \\
1 \\
\end{tabular} & \begin{tabular}{|l} 
Llibre \\
2 \\
\end{tabular} & \begin{tabular}{|l|} 
Llibre \\
3 \\
\end{tabular} & \begin{tabular}{|l} 
Llibre \\
4 \\
\end{tabular} \\
\hline Consonança lleial & 922 & $11.4 \%$ & 31 & 78 & 266 & 497 & 50 \\
\hline Lleonismitat simple fem. & 2567 & $31.7 \%$ & 91 & 185 & 832 & 1315 & 144 \\
\hline Lleonismitat simple masc. & 264 & $3.3 \%$ & 15 & 23 & 70 & 140 & 16 \\
\hline Total lleonismitats simples & 2831 & $34.9 \%$ & 106 & 208 & 902 & 1455 & 160 \\
\hline Lleonismitat perfecta fem. & 691 & $8.5 \%$ & 26 & 46 & 214 & 373 & 32 \\
\hline $\begin{array}{l}\text { Lleonismitat perfecta } \\
\text { masc. }\end{array}$ & 68 & $0.8 \%$ & 4 & 8 & 22 & 27 & 7 \\
\hline $\begin{array}{l}\text { Totat lleonismitats } \\
\text { perfectes }\end{array}$ & 759 & $9.4 \%$ & 30 & 54 & 236 & 400 & 39 \\
\hline Lleonismitat plusq. fem. & 119 & $1.5 \%$ & 2 & 7 & 51 & 55 & 4 \\
\hline Lleonismitat plusq. masc. & 11 & $0.1 \%$ & & 1 & 3 & 7 & -- \\
\hline $\begin{array}{l}\text { Lleonismitat plusq. més } \\
\text { completa }\end{array}$ & 43 & $0.5 \%$ & & 1 & 15 & 25 & 2 \\
\hline Total lleonismitats plusq. & 173 & $2.1 \%$ & 2 & 9 & 69 & 87 & 6 \\
\hline Total general lleonismitats & 3763 & $46.4 \%$ & 138 & 271 & 1207 & 1942 & 205 \\
\hline Equívocs lleials & 48 & $0.6 \%$ & & 5 & 13 & 28 & 2 \\
\hline Equívocs contrafets 1 & 20 & $0.2 \%$ & & 4 & 9 & 7 & -- \\
\hline Equívocs contrafets 2 & 19 & $0.2 \%$ & 1 & 2 & 6 & 9 & 1 \\
\hline Equívocs contrafets 3 & 604 & $7.5 \%$ & 22 & 34 & 191 & 326 & 31 \\
\hline Derivatius per un so o s. & 10 & $0.1 \%$ & & & 4 & 6 & -- \\
\hline $\begin{array}{l}\text { Derivatius per diversos } \\
\text { sons o s. }\end{array}$ & 3 & $0.0 \%$ & & 1 & 1 & 1 & -- \\
\hline Total derivatius & 13 & $0.1 \%$ & & 1 & 5 & 7 & -- \\
\hline Rims meritoris & 742 & $9.2 \%$ & 21 & 25 & 144 & 492 & 60 \\
\hline Accentuals & 2 & $0.0 \%$ & & 1 & 1 & 0 & -- \\
\hline Utrisonants-cons. lleial & 5 & $0.1 \%$ & & & 1 & 2 & -- \\
\hline Utrisonants-lleonisms. & 24 & $0.3 \%$ & 2 & 3 & 8 & 10 & 1 \\
\hline Total utrisonants & 80 & $1.0 \%$ & 2 & 8 & 16 & 52 & 2 \\
\hline
\end{tabular}

Recordeu que els rims acordants i els diccionals sovint se solapen. 


\section{ANNEX 2}

\section{Rims equívocs lleials a l'Espill}

cosir qu és roma. / La cort de Roma (2769-70)

diu que no y creu; / ffent-li la creu, (3221-22)

lenya molt més, / pi sech y més [de metre] (3617-18)

A totes hores / ses belles Hores (3993-94)

és en la Seu, / sabeu on seu? (4269-70)

posant a part, / suposà part, (4771-72)

ha mi n la cara: / molt me fon cara (5049-50)

per culpa sua, / ella tant sua (5295-96)

Ell fóra viu! / Mala les viu! (5325-26)

a quants hi vénen, / a tants se venen. (5427-28)

canten a prima / ab sa veu prima (5477-78)

ni s'ou, ni 's veu; / ha la llur veu, (5559-60)

Davall lo sol, / Josep tot sol (6625-26)

brutal tan fer, / l'on si u sap fer (6757-58)

Lo marit comte / donà per comte [compte] (7375-76)

de pols a pols; / sobre la pols (7947-48)

han falsa pagua, / si dona ls pagua, (8229-30)

tantost a coure, / morter de coure (8319-20)

e cava mena; / lo molí mena (8511-12) [ $i$ sols dos versos més avall:

la tirant, serra, / davall la serra (8515-16)

He per llur cuyta / no serà cuyta (8863-64)

o d'altres més, / al setén mes (8947-48)

per l'ayre volen, / entren hon volen (9737-38)

obre la porta / he a Déu porta (11873-74)

sis anys de tornes / perquè rich tornes (12307-08)

a Déu ministres [verb] / als seus ministres (12529-30)

sa plasent cara / de mare cara (12763-64)

en les mans palmes; / he tocant palmes (13235-36)

quint terra cuyta--, / crexent ab cuyta (13803-04)

a Déu n’à fet. / Aquest de fet (14489-90)

tant com ne cap / en lo seu cap (14631-32)

no $n$ porta gens, / car moltes gens (15181-82)

alguna part; / les més, a part (15201-02)

plau a les gens, / profit no gens (16173-74) 


\section{Mostra de rims utrisonants (en sentit ampli) a l'Espill}

Serien consonança lleial:

honor-or (3751-52); fos-os (10309-10); cos-socós (13561-62), açò-lliçó (14979-80), entre altres.

Serien lleonismitats contrafetes:

tisores-dos hores (889-90) i preycador-Boca d'Or (11813-14)

Serien lleonismitats lleials:

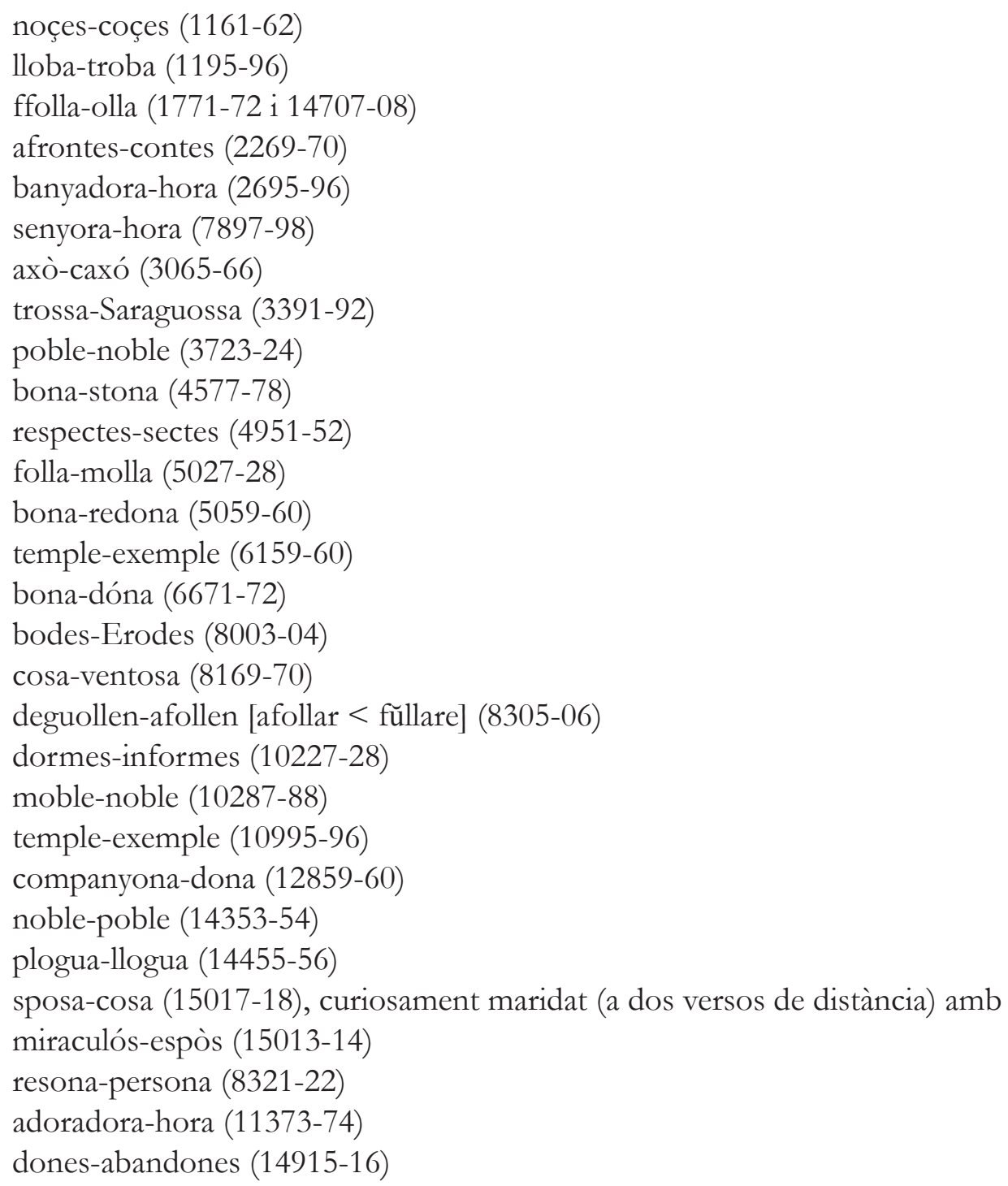

Serien sonança lleial (mostra): 


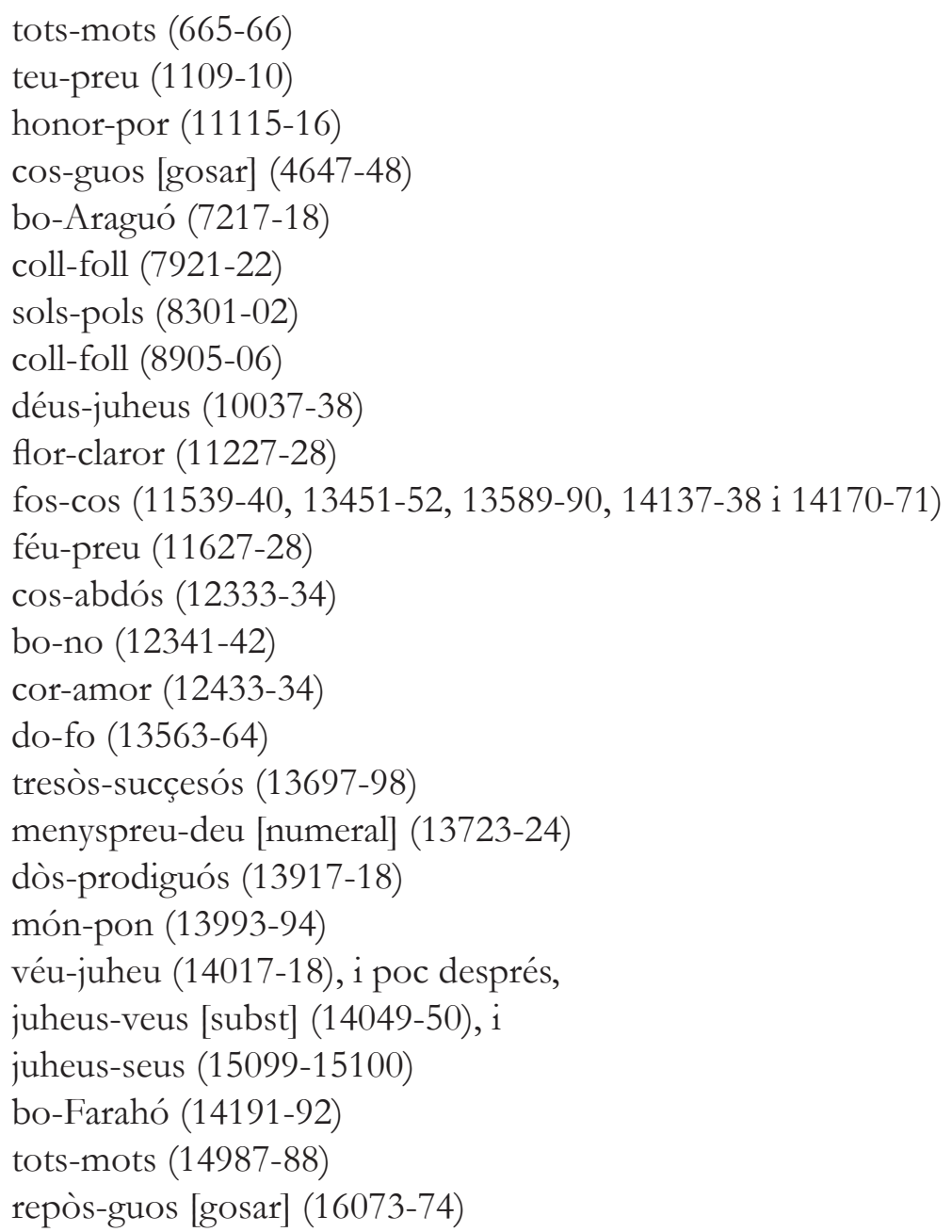

